\title{
Administrative issues of prohibitions on online information dissemination
}

\section{S. V. Simonova ${ }^{1}$}

${ }^{1}$ P. G. Demidov Yaroslavl State University, 14 Sovetskaya str., Yaroslavl 150003, Russian Federation

DOI: $10.18255 / 1996-5648-2021-1-84-91$

Research article Full text in Russian

The article deals with the limits and the implementation features of the prohibitions imposed on modern information dissemination process. The author provides the analysis of existed law-enforcement approaches to the definition of prohibited information and its distinction from related terms. In conclusion the suggestions on improving administrative legal proceedings on blocking information are given.

Keywords: information; websites; information restrictions; the website's owners

\section{INFORMATION ABOUT AUTHORS}

\begin{tabular}{l|l} 
Simonova Snezhana V. & $\begin{array}{l}\text { E-mail: snezh-simonova@yandex.ru } \\
\text { Cand. Sc. (Jurisprudence) Senior lecturer }\end{array}$
\end{tabular}

Funding: RFBR and EISR, project No 20-011-31346 


\section{Административно-процессуальные аспекты реализации запретов распространения информации в сети «Интернет»}

\section{С. В. Симонова ${ }^{1}$}

${ }^{1}$ Ярославский государственный университет им. П. Г. Демидова, ул. Советская, 14, Ярославль, 150003, Российская Федерация

DOI: $10.18255 / 1996-5648-2021-1-84-91$

Научная статья УДК 342.7

Полный текст на русском языке

В статье исследуются содержание и особенности реализации запретов распространения информации в сети «Интернет». Автор анализирует сложившиеся в современной правоприменительной практике подходы к определению понятия запрещенной информации и к ее отграничению от смежных явлений. В заключение формулируются предложения по совершенствованию отдельных аспектов административного судопроизводства по делам о признании информации в сети «Интернет» запрещенной к распространению.

Ключевые слова: информация; сайты; ограничение доступа к информации; владельцы сайтов

\section{ИНФОРМАЦИЯ ОБ АВТОРАХ}

Симонова Снежана Владимировна $\mid$ E-mail: snezh-simonova@yandex.ru Кандидат юридических наук, старший преподаватель

Финансирование: РФФИ и ЭИСИ, проект № 20-011-31346

Обеспечение права граждан на информационную безопасность определяется отечественными стратегическими документами в качестве одного из важных приоритетов российской государственной политики ${ }^{1}$. Провозглашение данного приоритета подкрепляется совокупностью

${ }^{1}$ См., например: Указ Президента РФ от 09.05.2017 № 203 «О Стратегии развития информационного общества в Российской Федерации на 2017-2030 годы» // СЗ РФ. 2017. № 20.,Ст. 2901.

(с) Симонова С. В., 2021

Статья открытого доступа под лицензией CC BY (https://creativecommons.org/licenses/by/4.0/) 
Симонова С. В.

юридических запретов, при помощи которых в фредеральном законодательстве фрормулируется перечень инфрормации, недопустимой к распространению. Несмотря на довольно подробное нормативное описание инорормационных угроз в киберпространстве, единый подход к оценке оснований ограничения распространения информации в современной правоприменительной практике отсутствует.

Прежде всего в Федеральном законе от 27.07.2006 № 149-ФЗ «Об информации, информационных технологиях и о защите информации» (далее - ФЗ № 149) разграничиваются понятия запрещценной $к$ распространению информации и информачии, распространение которой ограничено. В частности, запрещенная инбормация определяется как информация, за распространение которой предусмотрена уголовная или административная ответственность (ч. 6 ст. 10). При этом все интернет-ресурсы, которые содержат запрещенную к распространению инорормацию, подлежат включению в единый реестр (ст. 15.1).

С другой стороны, в ФЗ № 149 предусмотрены особые процедуры ограничения доступа к информации, распространяемой с теми или иными «нарушениями» отдельных законодательных актов. С учетом того, что механизм данного ограничения не связан с использованием обозначенного выше реестра, можно предположить, что под нарушающей закон информацией понимается не что иное, как инбормация, ограниченная $\kappa$ распространению.

Однако, несмотря на все обозначенное выше, содержательное разграничение запрещенной информации и информации, ограниченной к распространению, в ФЗ № 149 проведено несколько искусственно.

Во-первых, распространение информации с нарушением закона (ст. 15.3, 15.5 Ф3 № 149 и пр.) образует составы преступлений или административных правонарушений так же, как и распространение информации, определяемой ФЗ № 149 в качестве запрещенной к распространению. $\mathcal{K}$ примеру, обработка персональных данных с нарушением нормативных требований является основанием привлечения оператора к административной ответственности. В то же время распространение данной информации не служит основанием включения интернет-ресурса в единый реестр, а, значит, анализируемый тип информации не относится к категории запрещенной.

Bо-вторых, как к запрещенной информации, так и к инорормации, ограниченной к распространению, применяются имеющие общее наименование, но различные организационные нюансы процедуры ограничения доступа. Указанное ограничение доступа преследует единые цели, которые не дифференцируются в зависимости от типа информации - цели за- 
щиты основ конституционного строя, прав и законных интересов других лиц и пр.

Отмеченная размытость формулирования в ФЗ № 149 общих подходов к определению правового режима запрещенной и ограниченной к распространению информации закономерно оборачивается рядом сложно разрешимых проблем правоприменительной практики. Новый виток актуальности данных проблем пришелся на 2019 год в связи со вступлением в силу изменений в Кодекс административного судопроизводства РФ (далее - КАС РФ), который был дополнен главой 27.1, регулирующей порядок осуществления административного судопроизводства по делам о признании информации в сети «Интернет» запрещенной к распространению.

1. Прежде всего, в российской правоприменительной практике на протяжении довольно длительного времени доминирует широкий и значительно «опережающий» положения ФЗ № 149 подход к определению понятия запрещенной инорормации. Фактически в качестве таковой правоприменитель во многих случаях рассматривает не только инбормачию, за действия по распространению которой следуют меръ уголовной или административной ответственности, но и информацию о действиях, квалияицируемых в качестве преступлений или административных правонарушений [1].

Например, распространение определенных сведений может рассматриваться с точки зрения пособничества как бормъ соучастия в преступлении (пособничество в террористической деятельности и пр.) $)^{2}$ либо бактора, побуждающего неопределенный круг лич к совершению преступлений (например, к приобретению и использованию документа об образовании за плату без прохождения обучения и итоговой аттестации) $)^{3}$. Следуя данной логике, основанием запрета распространения инорормации можно считать оценку содержания публикаций в сети «Интернет» через призму умышленного создания условий для совершения преступлений, направленности на совершение последних. В отдельных случаях запрет на публикацию информации выводится из положений гражданского законодательства, запрещающего злоупотребление правол. В качестве злоупотребления, направленного на причинение вреда потребителям информационных услуг, в практике рассматривается распространение информации о выдаче медицинских справок без прохождения освидетельствования ${ }^{4}$.

${ }^{2}$ См.: Определение Верховного Суда РФ от 26.02.2013 № 6-КГПР-13-1 // СПС «КонсультантПлюс».

${ }^{3}$ См.: Апелляционное определение Омского областного суда от 11.09.2013 по делу № 335962/2013 // СПС «КонсультантПлюс».

${ }^{4}$ См.: Апелляционное определение Московского городского суда от 04.07.2016 по делу № 33-25473/2016 // СПС «КонсультантПлюс». 
Симонова С. В.

Интересно, что на уровне ведомственных разъяснений имеется противоположная практика. Например, в 2017 году Минкомсвязи России подчеркнуло предположительный характер утверждения о том, что размещение информации о продаже контрафактной продукции на сайтах в свободном доступе является приготовлением к преступлениям и подстрекает граждан к их совершению5.

Как видится, подобные интерпретации являются ярким примером расширительного толкования положений закона и фактически направлены на установление новых правил поведения. Выводы судов о запрете распространения информации как о достаточном основании ограничения доступа к информационному ресурсу делаются на основе многоэтапной интерпретации законодательных положений, устанавливающих общие запреты либо допустимые цели ограничения прав. С этих позиций запрещенная к распространению информация, по мнению органов прокуратуры и судов, представляет опасность для жизни и здоровъя людей, достоинства и неприкосновенности личности, нарушает права и законные интересы неопределенного круга лич, противоречит челям и задачам законодательства, подрывает основы конституциионого строя или сочиальную стабильность в обществе, нарушает законодательные запреты ${ }^{6}$.

Предложенный подход стирает границы между понятиями запрещенной информации и информации ограниченного распространения. Как следствие, вывод о том, что распространяемая в цифровой среде информация сопряжена с вероятными угрозами в отношении охраняемых законом ценностей, уже может являться достаточным основанием для ограничения доступа к интернет-ресурсу. Кроме того, при применении к оценке информации теста на создание условий для совершения преступлений не становится понятнее, идет ли речь о приготовлении к преступлению или о покушении на его совершение.

Сама же по себе возможность определения действий по распространению информации в сети «Интернет» с позиции неоконченного преступления видится крайне спорной. В соответствии с Уголовным кодексом РФ уголовная ответственность наступает лишь за приготовление к тяжкому и особо тяжкому преступлению. В то же время большая часть составов преступлений против порядка управления (например, предусмотренных ст. 324, 327 УК РФ и пр.) является преступлениями небольшой или сред-

${ }^{5}$ См.: Письмо Минкомсвязи от 22.06.2017 № П17-1-200-14741 // СПС «КонсультантПлюс».

${ }^{6}$ Представленная автором интерпретация объема понятия запрещенной к распространению информации основывается на анализе проанализированных выше судебных решений. 
ней тяжести. Соответственно, уголовная ответственность лица, которое, к примеру, распространяет в сети «Интернет» информацию о продаже документов, подтверждающих предоставление специального права на управление транспортным средством, как за приготовление к сбыту исключается. Едва ли корректно при данных условиях определять информацию о продаже подобного документа как информацию, за распространение которой предусмотрена уголовная ответственность.

Как представляется, решение задачи ограничения распространения в сети «Интернет» информации, размещаемой в целях создания условий для последующего совершения преступлений, возможно и в рамках существующих механизмов. Так, положениями Федерального закона от 13.03.2006 № 38-ФЗ «О рекламе» запрещается распространение рекламных сообщений, побуждающих к совершению противоправных деяний. За нарушение законодательства о рекламе предусмотрены меры административной ответственности, в связи с чем указанная реклама может быть определена через призму запрещенных к распространению сведений. В силу этого необходимость в каких-либо сложных и двусмысленных конструкциях отпадает.

Кроме того, надо иметь в виду, что признание инорормации в качестве запрещенной к распространению может влечь за собой ограничение доступа к интернет-ресурсу. При принятии такого решения следует исходить из соображений недопустимости произвольного ограничения доступа к информации и принимать во внимание контекст публикации записи и возможные последствия блокировки ${ }^{7}$ с тем, чтобы информация признавалась запрещенной в целях решения узкой задачи удаления определенных сведений из сети «Интернет».

2. Неоднозначен и ряд процессуальных вопросов административного судопроизводства по делам о признании информации в сети «Интернет» запрещенной к распространению.

Bo-nервых, в пояснении нуждаются положения ч. 4 ст. 265.2 КАС РФ, определяющие необходимость соблюдения административным истчом предусмотренного законом досудебного порядка признания инбормации в сети "Интернет" инфбормацией, распространение которой запрещено. В ФЗ № 149 понятие такого досудебного порядка не определено: в ч. 5 ст. 15.1 данного акта решение суда определяется в качестве одного из альтернативных оснований для включения сведений в Единый реестр доменных имен, указателей страниц сайтов в сети «Интернет» и сетевых

7 Опираясь на указанные соображения, Верховный суд РФ при рассмотрении одного из дел признал содержание комментариев к одной из интернет-записей недостаточным основанием для признания информации запрещенной. Более подробно см.: Кассационное определение Верховного Суда РФ от 19.10.2018 № 4-КГ18-57 // СПС «КонсультантПлюс». 
Симонова С. В.

адресов. Какое-либо упоминание о необходимости обязательного, предваряющего судебные процедуры обращения в федеральный орган исполнительной власти в Законе об информации отсутствует.

Между тем в юридической литературе сформулировано весьма обоснованное предложение о введении обязательного досудебного порядка признания информации, размещенной в сети «Интернет», запрещенной к распространению [2, с. 40-44]. По мнению ряда ученых, активное применение административного порядка при последующем судебном контроле будет способствовать предупреждению случаев необоснованного ограничения доступа к интернет-ресурсам [3, с. 48-52].

Во-вторых, не вполне однозначен круг ответчиков, $к$ которым может быть предъявлено требование о признании инбормачии в качестве запрещенной $к$ распространению в порядке главы 27.1 КАС РФ.

В соответствии с одним из разъяснений Верховного суда РФ, в качестве ответчика по административным делам о признании запрещенной информации, причиняющей вред здоровью и (или) развитию детей, привлекается Роскомнадзор ${ }^{8}$. С учетом того, что именно Роскомнадзор занимается исполнением судебных решений об ограничении доступа к интернет-ресурсам, отмеченная позиция видится весьма обоснованной.

С другой стороны, в правоприменительной практике сложился подход, в соответствии с которым надлежащими ответчиками по анализируемой категории дел признаются владельцы сайтов в сети «Интернет», где размещена информация, в отношении которой ставится вопрос о запрете, либо административные ответчики не устанавливаются.

Как видится, признание ответчиками по соответствующей категории дел владельцев сайтов противоречит правилу, закрепленному в ч. 5 ст. 38 КАС РФ. В соответствии с ним допускается возможность привлечения в качестве административных ответчиков граждан, их объединений и организаций, не обладающих государственными или иными публичными полномочиями, лишъ в случаях, установленных КАС РФ. Такие случаи в главе 27.1 КАС РФ, как известно, не определены.

С другой стороны, в случае если владельцы сайта не будут привлекаться к участию в рассмотрении судами требований об ограничении доступа к интернет-ресурсам, существует риск того, что они узнают о заявленном требовании лишь в момент блокировки сайта. Тем самым будет нарушаться их право на защиту. В целях предупреждения подобной практики в КАС РФ целесообразно предусмотреть правило об обязанно-

${ }^{8}$ См.: Обзор судебной практики Верховного Суда РФ № 1 (2018), утв. Президиумом Верховного Суда РФ 28.03.2018; Бюллетень судебной практики по административным делам Свердловского областного суда (первый квартал 2018 г., утв. Постановлением Президиума Свердловского областного суда от 16.05.2018) // СПС «КонсультантПлюс». 
Административно-процессуальные аспекты реализации запретов...

сти суда привлекать к участию в деле владельцев тех интернет-ресурсов, на которых размещена предположительно запрещенная информация.

Кроме того, в КАС РФ важно разъяснить возможность процессуального соучастия на стороне административных ответчиков при рассмотрении анализируемой категории дел, а также перечень тех действий, которые должен предпринять суд в целях поиска всех заинтересованных лиц на этапе подготовки дела к судебному разбирательству. Реализация данных рекомендаций создаст условия для внесудебного удаления запрещенного контента.

Таким образом, анализ материалов правотворческой и правоприменительной практики обнаруживает потребность в уточнении понятия информации, запрещенной к распространению в Российской Федерации. На законодательном уровне следует отказаться от не имеющего объективного и разумного основания разграничения категорий запрещенной информации и информации, ограниченной к распространению. С другой стороны, в правоприменительной практике должна исключаться тенденция расширительного толкования понятия запрещенной информации как сведений о действиях, за совершение которых предусмотрена уголовная или административная ответственность. В пояснении на уровне КАС РФ нуждаются положения о содержании досудебного порядка признания инорормации в качестве запрещенной к распространению (ч. 4 ст. 265.2), о круге ответчиков по требованиям о признании информации запрещенной, а также возможности процессуального соучастия.

\section{Ссылки}

1. Али M. 3. Ограничение доступа к информационным ресурсам в сети Интернет (практические проблемы признания информации запрещенной к распространению) // Право в сфрере Интернета: сборник статей / рук. авт. кол. и отв. ред. М. А. Рожкова. М.: Статут, 2018. СПС «КонсультантПлюс».

2. Бывальцева С. Г., Макарова Н. Г. Анализ законопроекта о внесении изменений в КАС РФ, касающихся порядка рассмотрения заявлений прокурора о признании запрещенной информации, распространяемой посредством сети Интернет // Административное право и процесс. 2019. № 4. С. 40-44.

3. Опалев Р. О. Проблемы ограничения доступа к информации в сети Интернет // Арбитражный и гражданский процесс. 2019. № 9. С. 48-52. 